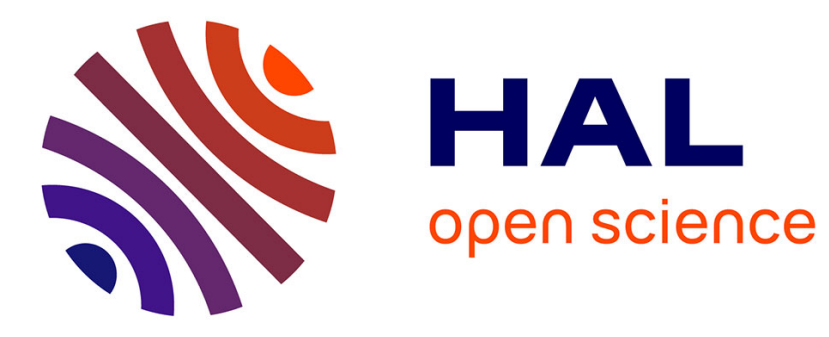

\title{
Xylella fastidiosa: Insights into an Emerging Plant Pathogen
}

\author{
Anne Sicard, Adam R. Zeilinger, Mathieu Vanhove, Tyler E. Schartel, Dylan \\ J. Beal, Matthew P. Daugherty, Rodrigo P. P. Almeida
}

\section{- To cite this version:}

Anne Sicard, Adam R. Zeilinger, Mathieu Vanhove, Tyler E. Schartel, Dylan J. Beal, et al.. Xylella fastidiosa: Insights into an Emerging Plant Pathogen. Annual Review of Phytopathology, 56, Annual Reviews, 2018, Annual Review of Phytopathology, 978-0-8243-1356-2. 10.1146/annurev-phyto080417-045849 . hal-02791754

\section{HAL Id: hal-02791754 \\ https://hal.inrae.fr/hal-02791754}

Submitted on 5 Jun 2020

HAL is a multi-disciplinary open access archive for the deposit and dissemination of scientific research documents, whether they are published or not. The documents may come from teaching and research institutions in France or abroad, or from public or private research centers.
L'archive ouverte pluridisciplinaire HAL, est destinée au dépôt et à la diffusion de documents scientifiques de niveau recherche, publiés ou non, émanant des établissements d'enseignement et de recherche français ou étrangers, des laboratoires publics ou privés. 


\title{
A REVIEWS
}

Annual Review of Phytopatbology

Xylella fastidiosa: Insights into an Emerging Plant Pathogen

\author{
Anne Sicard ${ }^{1,2}$ Adam R. Zeilinger, ${ }^{1}$ Mathieu Vanhove,${ }^{1}$ \\ Tyler E. Schartel, ${ }^{3}$ Dylan J. Beal, ${ }^{1}$ \\ Matthew P. Daugherty, ${ }^{3}$ and Rodrigo P.P. Almeida ${ }^{1}$ \\ ${ }^{1}$ Department of Environmental Science, Policy and Management, University of California, \\ Berkeley, California 94720, USA; email: rodrigoalmeida@berkeley.edu \\ ${ }^{2}$ Biologie et Génétique des Interactions Plant-Parasite, UMR 0385, Centre de Coopération \\ Internationale en Recherche Agronomique pour le Développement-Institut National de la \\ Recherche Agronomique-Montpellier SupAgro, Campus International de Baillarguet, \\ 34398 Montpellier CEDEX 05, France \\ ${ }^{3}$ Department of Entomology, University of California, Riverside, California 92521, USA
}

Annu. Rev. Phytopathol. 2018. 56:181-202

First published as a Review in Advance on June 11, 2018

The Annual Review of Phytopatbology is online at phyto.annualreviews.org

https://doi.org/10.1146/annurev-phyto-080417045849

Copyright (c) 2018 by Annual Reviews. All rights reserved

\section{ARMULCCONNECT}

www.annualreviews.org

- Download figures

- Navigate cited references

- Keyword search

- Explore related articles

- Share via email or social media

\section{Keywords}

ecology, evolution, host adaptation, risk assessment, vector, climate change

\section{Abstract}

The bacterium Xylella fastidiosa re-emerged as a plant pathogen of global importance in 2013 when it was first associated with an olive tree disease epidemic in Italy. The current threat to Europe and the Mediterranean basin, as well as other world regions, has increased as multiple $X$. fastidiosa genotypes have now been detected in Italy, France, and Spain. Although $X$. fastidiosa has been studied in the Americas for more than a century, there are no therapeutic solutions to suppress disease development in infected plants. Furthermore, because $X$. fastidiosa is an obligatory plant and insect vector colonizer, the epidemiology and dynamics of each pathosystem are distinct. They depend on the ecological interplay of plant, pathogen, and vector and on how interactions are affected by biotic and abiotic factors, including anthropogenic activities and policy decisions. Our goal with this review is to stimulate discussion and novel research by contextualizing available knowledge on $X$. fastidiosa and how it may be applicable to emerging diseases. 


\section{INTRODUCTION}

In October 2013, scientists reported that the bacterium Xylella fastidiosa was present in the southern Italian region of Apulia (129). In most circumstances, an aggressive effort to contain and eradicate $X$. fastidios $a$ would have been implemented, thereby limiting the spread of the bacterium to other regions in Italy and Europe or even eradicating it. However, following the October 2013 report, expected and unexpected cascades of events led to the establishment of $X$. fastidiosa in various regions along the Mediterranean basin. As with past epidemics, the emergence of $X$. fastidiosa in Europe has motivated much research into the ecological and evolutionary drivers of the establishment and spread of this plant pathogen. Our goal in this review is to place recent knowledge on $X$. fastidiosa within epidemiological and agroecological contexts and outline how this knowledge may be applied to risk assessment and management of other emerging epidemics of this pathogen worldwide.

\section{BRIEF HISTORICAL PERSPECTIVE}

In 1892, Newton Pierce was the first to report on a disease caused by $X$. fastidiosa (111). Pierce studied an epidemic of California vine disease in Southern California that had devastating consequences to the grape industry in the region; the disease was later called Pierce's disease (PD). More than a century later, despite being the most studied and best understood $X$. fastidiosa disease, PD remains a significant problem to the grape industry in California (141). Other than a 1930-1940 epidemic that led to major breakthroughs such as the identification of insect vectors, $X$. fastidiosa and the diseases it causes remained poorly characterized until the late 1970s when it was first cultured in vitro (40). The bacterium remained a pathogen of interest primarily in the United States until 1987, when it emerged in Brazil and was associated with a citrus disease $(21,64)$. The impact of $X$. fastidiosa on the citrus industry led to the development of a research community in Brazil that eventually sequenced the genome of the bacterium in 2000 (132). At the same time, another PD epidemic in Southern California devastated the local wine industry after the establishment of an invasive vector, Homalodisca vitripennis $(14,137)$. These two epidemics initiated a two-decade period of intensive study of $X$. fastidios $a$ and resulted in an unprecedented accumulation of knowledge concerning this pathogen (42). Although research on X. fastidiosa continues to focus on grapevines and citrus, new epidemics in other crops in other regions of the United States, as well as the emergence of the pathogen in Europe, are bound to increase and diversify knowledge about this bacterium and the diseases it causes. In 2013, Purcell (115) provided a more thorough historical perspective of $X$. fastidiosa prior to current epidemics.

\section{Emergence of Xylella fastidiosa in Europe}

$X$. fastidiosa has been a target of concern for decades, including efforts to understand why it had not already established in Europe (e.g., 114). Before 2013, there were only sporadic reports of $X$. fastidiosa detection in Europe (50), but they were not independently confirmed and did not raise concerns. Thus, the 2013 report of a new olive tree disease associated with $X$. fastidios $a$ in Italy was troubling but not unexpected (129). The presence of $X$. fastidiosa in Europe led the European Commission to require mandatory surveys of the bacterium in member countries. These surveys led to the determination that $X$. fastidiosa is established in France (island of Corsica and southern region of Côte d'Azur) and Spain (Balearic islands and province of Valencia) (9, 44, 105, 124). Reports from other countries exist but do not appear to include open-air outbreaks and were limited to isolated detection events (https://gd.eppo.int/taxon/XYLEFA/distribution). 
A strong case has been built linking the importation of $X$. fastidiosa-infected plant material from Central America to the emergence of the olive tree disease in Italy. Evidence shows that a single genotype has established in Apulia $(60,73,87,90)$ and that imported plant material infected with different strains of $X$. fastidios $a$ has been intercepted at ports and markets in different European countries $(12,87)$. A different picture, however, is emerging from France and Spain. Whereas Italy has a localized disease epidemic associated with a single pathogen introduction, the other two countries appear to have had multiple independent introductions of different $X$. fastidiosa genotypes that are widely spread in the landscape $(9,44,105,124)$. The lack of a localized disease epidemic and the spatial distribution of different genotypes (e.g., throughout Corsica and Balearic Islands) suggest that $X$. fastidiosa was not very recently introduced. We expect the temporal dynamics of these introductions to be understood better once more genomic and other types of data become available.

\section{ESSENTIALS OF XYLELLA FASTIDIOSA BIOLOGY}

$X$. fastidiosa is a xylem-limited bacterium in the family Xanthomonadaceae (Gammaproteobacteria) that is an obligatory colonizer of plant and insect hosts (143). The list of plants associated with $X$. fastidiosa includes more than 350 species; we expect that number to increase as research on new epidemics in the Mediterranean accumulates (52). However, the list of host species is largely based on field-observed associations of $X$. fastidiosa hosts, both symptomatic and asymptomatic, and limited research has been done under controlled conditions to confirm these associations. Furthermore, despite this large number of host plants, $X$. fastidiosa is a bacterial species with various well-supported phylogenetic clades, each of which has a more limited host range. In fact, when pathogenicity to plants is considered, $X$. fastidios a phylogenetic clades have a limited host range. An alternative view based on currently available data is that $X$. fastidiosa is associated with a large number of plant species as a commensalist, but a limited number of clades and particular bacterial genotypes are responsible for and specific to a small number of plant diseases.

Unlike plant disease, the association of X. fastidiosa with hemipteran vectors, the only means of natural dissemination, is not the outcome of particular insect-pathogen combinations. There are two main insect vector groups, the sharpshooter leafhoppers (Cicadellidae subfamily Cicadellinae) and spittlebugs (Cercopoidea, families Aphrophoridae, Cercopidae, and Clastopteridae), both of which are xylem-sap feeders $(68,131)$. In 1965, Frazier hypothesized that all insect species in these groups should be considered $X$. fastidios $a$ vectors, a proposal that has stood the test of time (57). Importantly, available data demonstrate that insect vectors are capable of transmitting all $X$. fastidiosa genotypes without specificity (4). Limited evidence exists for cicadas (Cicadoidea) as $X$. fastidiosa vectors; this group requires further investigation, considering the large populations in certain Mediterranean regions $(77,106)$.

\section{Plant and Insect Colonization}

Plant colonization by $X$. fastidiosa is a gradual process in which blockage of individual vessels due to bacterial population growth, associated plant responses (e.g., tyloses), and concomitant spread among vessels via pit membranes reduce sap flow in the xylem network (10, 95). Pathogen cell density mediates processes linked to plant colonization and movement, which are upregulated at low cell density; by contrast, $X$. fastidiosa populations switch to an insect acquisition and colonization phenotype that precludes further plant colonization at high cell densities $(22,96)$. The nature of this molecular switch is likely linked to X. fastidiosa biology (4). Xylem-sap-feeding insects are negatively impacted by plant water stress and increases in water column tension-phenomena that are also triggered by $X$. fastidiosa infection $(7,93)$. In addition, water-stressed plants often 
exhibit symptoms, such as leaf scorch, that are common consequences of pathogenic $X$. fastidiosa infections (93). Research has shown that sharpshooter vectors visually discriminate against plants exhibiting leaf scorch symptoms, with or without $X$. fastidiosa $(38,92)$. As previously proposed, we interpret this cell-density-dependent behavior as an adaptation that permits the bacterium to colonize plants successfully yet limits excessive multiplication that would lead to disease symptoms and thus decreased host plant attractiveness to insect vectors. In fact, $X$. fastidiosa spread has been mathematically and experimentally demonstrated to peak prior to full disease symptom development, a point at which within-plant bacterial populations are large and acquisition by vectors is maximized, but insects strongly discriminate against such plants (39). Finally, although X. fastidiosa may negatively impact plants in different ways, the only evidence of potential negative effects on insect vectors is recent work demonstrating that the population size of a chitinase mutant strain did not increase in insect vectors when compared with a wild-type control (81), suggesting that vector colonization by $X$. fastidiosa involves chitin degradation. Although this could impact insect hosts, there is no direct evidence that $X$. fastidiosa colonization leads to vector behavioral or fitness-related changes.

\section{Vector Transmission}

Several aspects of $X$. fastidiosa-vector interactions relevant to plant-to-plant transmission have been studied, allowing for broad generalizations to be summarized. First, as mentioned above, there is no evidence of $X$. fastidiosa genotype-vector specificity, indicating that biological and molecular interactions between the pathogen and vector are phylogenetically conserved. Once acquired from plants, $X$. fastidios $a$ attaches to and colonizes specific regions in the foregut of vectors (i.e., precibarium and cibarium) to form a persistent biofilm $(76,81,118)$. The fact that $X$. fastidiosa is propagative and persistent yet noncirculative in insect vectors has been demonstrated with several lines of evidence, including the lack of transovarial $(58)$ and transstadial $(5,117)$ transmission of bacterium in vectors, microscopical observations of the foregut $(6,17,118)$, transmission studies with aging insects $(6,69)$, and other approaches demonstrating bacterial persistence and multiplication in vectors $(69,76,81)$.

Even though $X$. fastidiosa forms a biofilm on the cuticular foregut of insect vectors, there is no detectable latent period required for transmission (117). In other words, transmission may occur immediately after acquisition, even if a biofilm has not developed. However, recent work indicates there may be a positive correlation between bacterial populations in insects and plant infection (30), suggesting that the dynamics of fluid flow in vector foreguts, coupled with specific probing behaviors during xylem-sap feeding that may facilitate pathogen detachment, are associated with $X$. fastidiosa inoculation. Yet the specific insect probing behavior(s) associated with $X$. fastidiosa inoculation into plants remains to be determined.

Finally, in the context of pathogen spread, it is important to dissociate the capacity of an insect species to transmit $X$. fastidiosa from its epidemiological role. $X$. fastidiosa transmission efficiency is impacted by various factors, including vector species (e.g., 34, 113), pathogen genotype (88), host plant species during pathogen acquisition and inoculation (88), bacterial populations within plants (70) and in different tissues in the same plant (36), vector preference for host plant type (121, $131)$, host plant tissues $(36,120)$, disease symptoms $(38,92)$, and temperature $(35,39)$. Therefore, although a large number of species are potential vectors of interest because of their inherent capacity to transmit $X$. fastidiosa, few are of epidemiological relevance in a specific disease system due to the large number of factors that affect the transmission process $(29,67,121)$. Although the factors listed above focus on the transmission process, aspects of vector and host plant biology and ecology, seasonality, and crop-management practices are also relevant. 


\section{Xylella fastidiosa Diversity and Host Plant Relationships}

Human-mediated movement of infected plant material has contributed to long-range dissemination of $X$. fastidiosa, but currently available genetic data indicate that three of the five $X$. fastidiosa subspecies are allopatric in origin. $X$. fastidiosa subsp. fastidiosa originated in Central America, subsp. multiplex in North America, and subsp. pauca in South America. Intersubspecific genetic introgressions between subsp. fastidiosa and subsp. multiplex may have led to the emergence of $X$. fastidiosa subsp. morus (100). The origin of $X$. fastidiosa subsp. sandyi is still debated (4); recent genomic data suggest that this clade clusters within subsp. fastidiosa $(60,87,89)$. Applying a phylogenetically representative genome sequence data set to $X$. fastidiosa taxonomy will likely clarify pending questions and lead to a revision of the group. As diversity is not a goal of this review, we direct readers to recent work on the topic $(28,60,89)$.

Genetically typing $X$. fastidiosa was challenging because this bacterium is naturally competent (79) and populations undergo extensive homologous recombination (HR) within and among phylogenetic clades $(3,28,75,98-101,103)$. In 2005, a multilocus sequence typing (MLST) scheme for X. fastidiosa was first introduced (130), leading to substantial improvement in understanding the phylogenetic relationships among isolates and how clades are organized in relation to both host plants and geographical location. When this article was prepared, 293 isolates from 76 plant species across three continents were publicly available in the X. fastidiosa MLST database (https://pubmlst.org/xfastidiosa/). In total, 55 sequence types (STs) are associated with 25 host plant families (for visualization of these data, see https://microreact.org/project/Hkwv1v7tZ). Note that the data set is geographically and host plant biased (e.g., most samples are from the United States, particularly California), limited in size, and based on a robust yet small number of loci $(n=7)$. Nevertheless, individual STs appear to be associated with a limited number of host plants. In other words, there is some host specialization in the form of disease relationships as determined from symptomatic plants in the field. ST-based X. fastidiosa identification using plant species previously infected elsewhere with a particular ST may be used to predict which host plant species are susceptible in a new region following an introduction. In other words, an almondinfecting ST previously described in the United States should also infect almonds in Spain, as was recently determined (124). We expect this hypothesis will be tested in a robust manner with a larger data set, given its potentially regulatory consequences for quarantine circumstances.

\section{Predictability of Host Jumps}

The potential for introduced pathogens to form novel associations with hosts and the ensuing consequences of these novel associations on disease dynamics are both of considerable interest because pathogens that form novel biotic associations in a naive geographic range may experience relaxed constraints on susceptibility and pathogenicity, which in turn facilitate disease epidemics $(138,139,147)$. Disease epidemics can start as the result of a pathogen jumping to novel hosts. Host jumps are likely common throughout evolutionary history and occur through a three-step process $(51,146)$. In the first step, a novel host is exposed to the emerging pathogen. In the following step, if the pathogen and novel host are compatible, the pathogen successfully infects the novel host. In the final step, the pathogen must sufficiently transmit among individuals within the novel host's populations.

The quarantine pathogen status of $X$. fastidiosa, coupled with its ability to colonize a large number of host plant species, highlights the practical importance of being able to predict novel host susceptibility to an individual ST or a phylogenetic clade of $X$. fastidiosa. The underlying factors associated with $X$. fastidiosa host plant specificity remain to be determined, but concerns about this question are of immediate relevance in areas where $X$. fastidiosa has been recently introduced. 
Using the above-mentioned MLST data set, we attempted to determine whether X. fastidiosa host shifts are predictable. Previous work with plant-pathogenic fungi, for example, indicated that pathogen host jumps tend to occur in plant species more closely related to those that the pathogen already infects (107). In other words, the closer the phylogenetic relationship between a host of concern and known pathogen host, the higher the likelihood that a host jump will occur. This elegant work follows expectations of coevolutionary theory and has had some success with plantpathogenic fungi. Thus, we performed a comparative host-pathogen coevolutionary analysis to investigate host plant-pathogen relationships. Maximum likelihood and Bayesian phylogenies were generated for host species and $X$. fastidiosa STs to test for coevolutionary congruence (as described in 85). No significant coevolutionary fit could be established (Supplemental Figure 1). These analyses confirm the difficulty of predicting $X$. fastidiosa host jumps.

In summary, currently available data suggest that using taxonomy derived from MLST data sets, i.e., ST number, to infer $X$. fastidiosa host range is both useful and problematic. Assignment of an isolate to a particular ST suggests which plant species may be susceptible to pathogenic infections on the basis of available knowledge. By contrast, the use of ST does not permit inferences on potential host range or host jumps. The level of genetic and phenotypic diversity currently used to define $X$. fastidiosa subspecies, although helpful taxonomically and in a biogeographic context, lacks resolution to provide reliable information regarding host range. We expect large wholegenome-sequence data sets to assist in addressing these limitations.

\section{ECOLOGICAL DRIVERS OF NOVEL DISEASE EPIDEMICS}

In an effort to deconstruct pathways leading to the emergence of $X$. fastidiosa diseases and outbreaks, we devised a simplistic flowchart as a framework for discussion (Figure 1). On the one hand, pathogen and vectors may be introduced or endemic, and human-mediated dispersal has the potential to impact vector geographical distributions. On the other hand, climatic conditions and associated changes to biotic and abiotic factors in the environment may impact the distribution of $X$. fastidiosa and associated vector species in the landscape, potentially increasing or decreasing disease prevalence. Finally, changes to agricultural practices such as crop intensification, irrigation, pest control, fertilization protocols, adoption of mixed crop fields or cover crops, and a myriad of other modifications to how land is used could also positively or negatively impact the role of $X$. fastidiosa as a pathogen. Here, we explore how different factors affect the emergence of $X$. fastidiosa diseases (also see examples in Supplemental Figure 2). We note that the factors presented here are split into distinct sections for arbitrary reasons, whereas in reality they are interconnected and interdependent.

\section{Contribution of Vectors to Xylella fastidiosa Outbreaks}

The potential for $X$. fastidiosa to invade, establish, and expand beyond its current range is partly predicated on the presence and distribution of insect vectors in a novel range. $X$. fastidiosa vectors are globally distributed $(33,50,121)$; however, most of these insect species are unlikely to contribute to novel $X$. fastidiosa outbreaks. In other words, the presence of vectors will not necessarily lead to outbreaks if $X$. fastidiosa is introduced, or is already present, in the landscape. Ultimately, the dynamic ecological interactions among vector, pathogen, and plants in the landscape are more likely to determine the importance of a particular vector species on pathogen spread than are the intrinsic biological characteristics of the insect. Factors that may modify the relative importance of a vector species in epidemics include, but are not limited to, pathogen genotype, vector phenology, vector natural infectivity (i.e., fraction of vectors in the population that are infective), vector diet breadth, vector mobility, plant phenology, plant water status, plant nutrient status, plant 


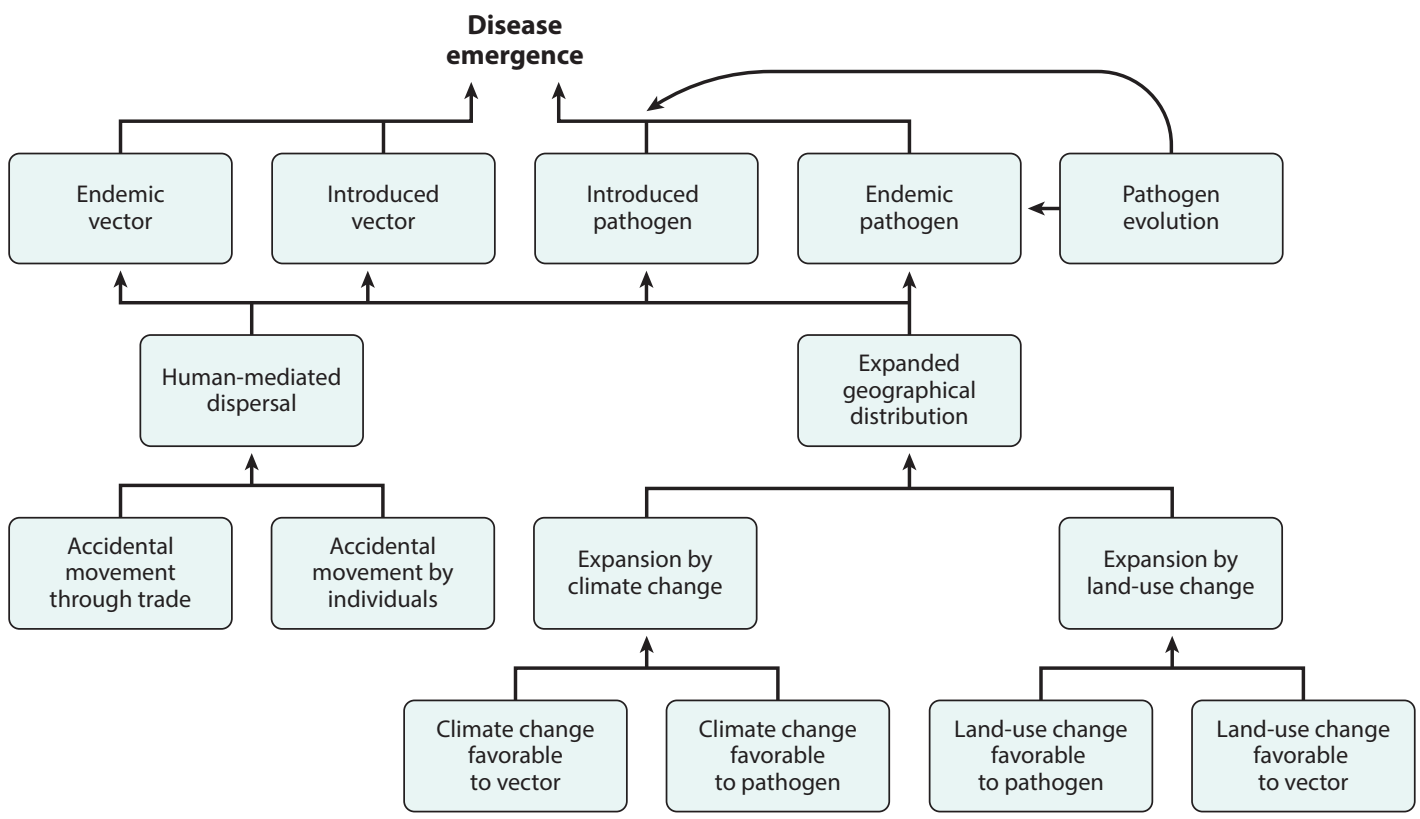

Figure 1

The emergence of Xylella fastidiosa diseases may be driven by a wide range of ecological factors, several of which likely interact with each other. Endemic and introduced insect vectors and pathogens play a central role in disease emergence, as they are subject to an array of factors that may contribute to novel disease or the geographical expansion and/or retraction of an existing disease. The flowchart highlights the hypothesized causal role of three major drivers of disease emergence: human-mediated introductions into new areas, climate change, and land-use change. Additionally, natural selection and other evolutionary processes may play a role. Pathogen evolution is likely to be most relevant for the emergence of novel $X$. fastidiosa disease, given the lack of vector species- $X$. fastidiosa genotype specificity. Supplemental Figure 2 exemplifies how this simplified diagram may be helpful for understanding disease emergence dynamics.

community composition, agricultural practices, and climate. Some, but not all, of these factors have been explicitly tested in X. fastidiosa diseases (e.g., 39, 61, 78).

To our knowledge, there is one example of a vector introduction leading to $X$. fastidiosa epidemics. Introduction of the sharpshooter $H$. vitripennis to Southern California and subsequent outbreaks of $\mathrm{PD}$ in that region demonstrate that an invasive vector species can alter the dynamics of an established X. fastidiosa disease system. The large population size of $H$. vitripennis, rather than transmission efficiency, is thought to be responsible for that outbreak $(14,34)$. High population densities in citrus groves and spillover into adjacent vineyards are considered critical elements of the role $H$. vitripennis plays in driving epidemics $(13,110)$. So far, $H$. vitripennis-linked epidemics in Southern California represent a unique case among $X$. fastidiosa outbreaks owing to the invasive status of the vector. Invasion of infectious $X$. fastidiosa vectors into a new region represents a distinct but related mode for disease emergence. Although this scenario deserves more attention, there are no currently reported $X$. fastidiosa epidemics where it has occurred.

\section{Introduced Pathogens in Landscapes That Favor Spread}

Introduction of $X$. fastidiosa-infected plant material has been associated with many cases of disease emergence across the world. Among the most dramatic examples is the introduction of $X$. fastidiosa subsp. fastidiosa, which led to $\mathrm{PD}$ in the United States more than a century ago 
$(102,148)$, its subsequent geographic expansion to Taiwan (140) and Spain (104), and the emergence of $X$. fastidiosa-related diseases in both countries. Another example is the introduction of plum-infecting $X$. fastidiosa subsp. multiplex from North America to South America; in this case, there is also evidence that the invasive strain contributed to the emergence of citrus variegated chlorosis (CVC) and coffee leaf scorch outbreaks in Brazil $(28,103)$. These examples of $X$. fastidiosa outbreaks are the result of successful introduction and establishment of this pathogen in new environments where the same crop plant species were cultivated.

\section{Role of Nonsymptomatic Pathogen Reservoirs}

Given its large number of asymptomatic host species, $X$. fastidiosa can easily be introduced and established in a new environment. Under natural conditions, most $X$. fastidiosa hosts are asymptomatic but can act as reservoirs that contribute to $X$. fastidiosa establishment, maintenance, and spread. The importance of asymptomatic reservoirs on disease epidemiology varies among pathosystems; for example, they appear important for PD in Northern California $(2,115)$ but not for CVC in Brazil (83). In addition, different pathogen multiplication rates have been observed in noncrop plants, suggesting that different hosts may contribute differentially to spread (e.g., 119). Therefore, it is important to consider the role of plant community composition and the prevalence of asymptomatic hosts on pathogen maintenance in the environment, how those are distinct from the relative role these plants may have on disease epidemiology, and how the role of reservoirs is highly dependent on the pathogen-host-vector system. The degree to which reservoir hosts contribute to epidemics may be related to the relative importance of primary versus secondary spread. Estimating primary and secondary spread is also not a trivial task; however, Parry et al. (108) describe a statistical method using spatiotemporal data on disease incidence for that purpose. Lastly, wild plants also maintain $X$. fastidiosa genetic diversity. They may also be hosts for mixed infections and, thus, potential facilitators of gene flow.

\section{Climatic Influences on the Distribution and Emergence of $X$. fastidiosa Diseases}

Climate is an important driver of $X$. fastidiosa disease. It influences the distribution and dynamics of vector populations, where and how host plants are grown, pathogen transmission, and plantpathogen infection dynamics. Manipulative studies have shown that higher temperatures generally favor greater feeding rates (136) and survival of sharpshooter vectors (135), higher transmission efficiency (35), higher $X$. fastidiosa multiplication rate (54), shorter incubation period and latency in plants (39), and greater persistence of infections in plants (86). These effects translate to different patterns in the field, especially with respect to plant infection; for example, lower winter temperatures are associated with seasonal reductions in X. fastidiosa infection level (133) and recovery of some infected plants $(53,84,116)$. Similarly, a combination of higher temperature and precipitation is associated with higher vector population densities in the field (e.g., 61), and precipitation is positively associated with $X$. fastidiosa establishment or spread $(15,16)$. These documented effects of climate may further explain broadscale patterns of $X$. fastidiosa pathosystems, such as the regional distribution of an invasive vector in the western United States (71), geographic differences in overwinter recovery of infected plants (86), the restricted distribution of many $X$. fastidiosa diseases to climatically moderate coastal regions for much of the United States (114), and the ultimate distribution of $X$. fastidiosa disease in invaded regions of Italy and the Mediterranean (15, 16). Collectively, available evidence indicates that understanding the precise nature of climatic relationships will yield insights into which regions not currently affected are most suitable for disease emergence if $X$. fastidiosa is introduced. 
Given underlying influences of temperature and precipitation on X. fastidiosa pathosystems, changes to climatic conditions may alter $X$. fastidiosa disease distribution or incidence. In general, global circulation models predict that many areas will experience warmer winter and nocturnal temperatures $(8,72,125)$, which in turn will contribute to increased precipitation in some areas but more frequent or severe drought in others $(59,65,125)$. Such changes may alter the suitability of areas where $X$. fastidios $a$ is not currently established and expand or shift disease distribution in nearby regions where it is endemic or has successfully invaded. Climate change may also lead to novel $X$. fastidiosa epidemics through the convergence of $X$. fastidiosa and novel host distributions. Alternatively, climate change may impact established or endemic $X$. fastidiosa pathosystems. In these cases, the agricultural system will likely migrate gradually to more suitable climates, as is happening for grapevine cultivation on the US West Coast (144), thereby contributing to the persistence of the pathosystem even if disease prevalence is somewhat altered. Thus far, studies that quantify the impact of climate change on $X$. fastidiosa distribution are largely lacking. An exception is a pair of studies that projected the potential extent of the $X$. fastidiosa invasion in Italy and throughout the region $(15,16)$. Those studies estimated that temperature and precipitation during the driest and wettest months contribute strongly to $X$. fastidiosa suitability, yet there were modest effects on disease expansion assuming current climate change projections. Additional studies of this type are needed, ideally drawing on a broader set of occurrence records for multiple $X$. fastidiosa subspecies, to generate robust predictions regarding the emergence of novel epidemics.

\section{Other Anthropogenic Factors}

Anthropogenic factors also play a role in generating novel pathogen-host associations that lead to disease epidemics. Human-mediated transport and introduction of pathogens through new trade routes among previously disconnected countries (1) and increasingly efficient means of transportation are believed to be responsible for generating cosmopolitan pathogens as well as for increasing the frequency and magnitude of disease outbreaks worldwide $(32,139)$. Human conversion of natural habitats into agroecosystems and monocultures as well as farming practices that place susceptible host populations in close proximity to each other further exacerbate the effects of introducing pathogens into a novel range (139). As a result, the combination of climate change and other anthropogenic factors generates serious concerns regarding the introduction and spread of invasive species, vectors, and pathogens at local to continental scales $(11,32,49$, $109,126,134)$.

Inadvertent transportation of pathogens with agricultural products is one means by which the first step of pathogen host jumping may be affected $(32,139)$. The recent introduction of $X$. fastidiosa into Italy may be one such case. Bosso et al. $(15,16)$ found that areas of intensive agriculture, complex cultivation patterns, olive groves, annual crops associated with permanent crops, orchards and vineyards, forest (essentially oak woodland), and Mediterranean shrubland were predictor variables associated with $X$. fastidiosa occurrence in Italy. In addition to these agricultural factors, $X$. fastidiosa infection in Italy may spread to multiple alternative hosts, although the distributions of these alternative hosts and the extent to which they co-occur with olive crops are not well understood $(91,112,128,129)$.

Whereas the introduction of pathogens into novel ranges may facilitate the first step of host jumping, agricultural practices can influence the degree or extent of pathogen-host plant compatibility and, thus, the disease prevalence and severity. In agricultural systems, increasing diversity of resistance genes within host plant populations can lead to reduced pathogen prevalence (18, $45,145,149)$. However, when there is little genetic diversity in resistance genes within a host plant population, a pathogen adapted to that particular host genotype may rapidly increase in 
frequency and lead to disease outbreak or epidemics (139). Agricultural practices where tracts of land are planted with monoculture crops with limited resistance diversity may thereby provide ideal conditions to facilitate pathogen establishment and spread. This is the case for most $X$. fastidiosa-susceptible crops and their cultivation practices; most are perennial plants such as grapevine, citrus, and almond trees that are vegetatively propagated as clones and planted in large numbers as monocultures.

In summary, human-mediated transportation and agricultural practices may be influential in determining the extent of $X$. fastidiosa distributions and, thus, the severity of potential $X$. fastidiosa epidemics. Introductions of $X$. fastidiosa into regions where (a) novel host plants are available, (b) little diversity of resistance to $X$. fastidiosa infection (and thus greater degrees of compatibility with $X$. fastidiosa) is present, and (c) limited spatiotemporal heterogeneity exists among compatible host species may promote $X$. fastidiosa-related disease epidemics. Yet on the basis of evidence from previous $X$. fastidiosa introductions where conditions may have imposed constraints on $X$. fastidiosa establishment and spread, two end results of $X$. fastidios $a$ introduction and establishment appear possible: the re-emergence of a known disease in a new area and/or the emergence of a new disease involving a new plant host (4).

\section{XYLELLA FASTIDIOSA EVOLUTION AND ADAPTATION}

Besides infecting the hosts to which it was preadapted, $X$. fastidios $a$ can also increase its host range. The major evolutionary forces likely involved in novel host adaptation include mutations, homologous and nonhomologous gene flow, and selection. Prophage regions represent a significant proportion of $X$. fastidiosa genomes, but they are also highly variable and may not be involved in host adaptation. Furthermore, although no experimental proof yet exists, available data provide indirect support for various processes leading to host adaptation.

\section{Support for Homologous Recombination on Host Adaptation}

HR may be one of the main drivers of $X$. fastidiosa evolution and adaptation (4, 28). Compared with point mutations, HR has been estimated to contribute approximately three times more to $X$. fastidiosa genetic diversity at the nucleotide level (130). HR in X. fastidiosa consists of an exchange of typically small DNA fragments (usually $\sim 1 \mathrm{~kb}$ ) between related genotypes (80). Because $X$. fastidiosa is naturally competent (79), coinfection of plant hosts and/or insect vectors may be a requirement for $\mathrm{HR}$, and as both occur $(23,31)$, genetic exchanges and thus recombination could happen in both environments. How common coinfections are in nature and how conducive these environments are for recombination remain to be determined, but the sympatric coexistence of multiple genotypes likely facilitates such processes. Although competency may be a conserved trait in X. fastidiosa, there are differences in transformation efficiency among subspecies and closely related strains (75).

Data indicate that $X$. fastidiosa subspecies have evolved in allopatry but have been brought into contact (human-mediated processes) on multiple occasions. These events provide clear examples of HR between endemic and introduced X. fastidiosa genotypes (e.g., 28) that are often associated with disease emergence. For example, recombination between endemic $X$. fastidiosa subsp. pauca and introduced $X$. fastidiosa subsp. multiplex in South America may have facilitated pathogen adaptation to citrus and coffee and, thus, are linked to the origin of coffee leaf scorch and CVC outbreaks in Brazil $(28,103)$. In a similar manner, X. fastidiosa subsp. morus infecting mulberry seems to have originated from large-scale HR events between $X$. fastidiosa subsp. fastidiosa and subsp. multiplex (100). These examples emphasize the risk of introducing new genotypes in areas 
where this pathogen has already been detected, as it increases the chances of gene flow and might thus result in an expansion of host range and the emergence of new diseases.

Although HR has been associated with emerging diseases, $X$. fastidios $a$ lineages that have split and are host specific may also recombine but remain genetically and ecologically isolated. Phylogenetic evidence indicating that CVC emerged from coffee-infecting $X$. fastidiosa has accumulated (e.g., 28). However, coffee- and citrus-infecting $X$. fastidiosa in Brazil, for example, are host specific and phylogenetically distinct (3), even though these crops and respective diseases occur sympatrically and share insect vectors. In fact, when adjacent citrus and coffee orchards were surveyed, all isolates were genetically split into coffee or citrus groups, indicating strong biological isolation (56). In summary, although $\mathrm{HR}$ has been frequently associated with $X$. fastidiosa host jumps and new diseases, even frequent gene flow among sympatric and closely related clades of $X$. fastidiosa may not be enough to break down biological barriers associated with host colonization. In other words, host adaptation and specificity appear to carry ecological costs and possibly select for aggressiveness.

\section{Laterally Transferred Elements}

Laterally transferred elements such as plasmids and integrated prophages play an important role in $X$. fastidiosa evolution and genetic diversity and could contribute to the ability of this species to infect new hosts. The $X$. fastidios $a$ flexible genome primarily comprises plasmids, integrated prophages, and genomic islands. The integrase genes of prophages could contribute to both the introduction of new genes and rearrangements. The most evident differences observed between $X$. fastidiosa subspecies genomes seem to be linked to phage-like sequences. This observation has led several authors to propose that laterally transferred elements mediate the divergence of lineages leading to host specificity $(43,98,142)$. Interestingly, in one studied case, the horizontally transferred gene pool was independently regulated in relation to the core genome (98). Whether laterally transferred elements are indeed involved in host speciation remains to be determined, but if they were, they would have to be shared by isolates infecting a given host.

Several plasmids harbored by different strains of $X$. fastidiosa have been described (122), but the functions of a significant fraction of plasmid-encoded genes remain unknown. These plasmids seem to lack some modules that would confer selective advantages to the strains harboring them (122). Nevertheless, one plasmid possesses a functional type IV secretion system enabling conjugation within and between subspecies $(19,123)$. Exchanges of plasmids have also been reported within $(66)$ and between subspecies $(60,66)$. These conjugative plasmids could increase the chance of acquisition of new features involved in pathogenicity or exploitation of new resources and adaptation to new environments. Even in the absence of direct selective pressure, conjugative plasmids may confer a fitness advantage to their host $(46,55)$.

\section{Mutations and Host Selective Pressure}

On the basis of four strains belonging to four subspecies, Doddapaneni et al. (48) have estimated that the average SNP and INDEL frequencies are 0.01 and 0.02 , respectively, per base pair of DNA. Although the effects of point mutations on $X$. fastidiosa adaptation to new hosts have been less studied than the role of HR, the recent infection of olive trees by $X$. fastidiosa subsp. pauca isolates highlights their importance. Studies $(60,87,90)$ have shown that all isolates from olive trees in Italy belong to the same ST that also contains Costa Rican isolates infecting oleander and coffee plants. Given the small number of SNPs that differentiate strains infecting olive trees from those infecting oleander or coffee, adaptation to this new host in Apulia likely results from a few mutations under selective pressure. Interestingly, infection of olive trees by this bacterium also 
occurs in Brazil and Argentina $(27,62)$. The olive strains from Brazil belong to another ST that includes coffee strains, pointing toward convergent evolution; by contrast, the strains in Argentina remain uncharacterized.

After a host jump, strong host selective pressures may purge less-fit genotypes from populations (24). Doddapaneni et al. (47) noticed that long internal branch lengths with groupings of short terminal branches that correspond to host-specific phylogenetic clades characterize phylogenetic trees of $X$. fastidiosa isolates. The authors hypothesized that this tree topology was the result of strong selective pressures. The lack of cross-infection between sympatric isolates infecting different hosts seems to corroborate this idea (e.g., 3, 56, 63). With few exceptions, most $X$. fastidiosa strains appear to be able to cause disease in only one or few crop species, pointing toward strong host speciation (e.g., 3, 101). In addition, replacement of local isolates (local populations) has not been reported to occur in nature, suggesting that isolates adapted to a given environment might be recalcitrant to invaders that could be less fit to local conditions (26). The genetic basis of host specificity remains to be determined, although whole-genome comparison of highly specialized isolates occurring in sympatry is likely to provide insights into this question.

\section{Hypothesis on Evolution of Host Adaptation}

Plant diversity is much higher in natural environments than in the ecological systems of monocultures of perennial hosts affected by $X$. fastidiosa. Because $X$. fastidiosa vectors are generally polyphagous, the probability that a given isolate in a natural environment will encounter the same host genotype is reasonably lower than in a monoculture. We suggest that a diverse plant community limits bacterial adaptation to a given host, selects for generalist genotypes that are not pathogenic, and generates and sustains a genetically diverse $X$. fastidiosa population in the landscape (Figure 2). As previously discussed, the prevailing hypothesis on $X$. fastidiosa biology posits that conflicting biological and ecological processes mediate within and between host colonization (22). In crop systems, once $X$. fastidiosa has adapted to a new host, isolates might be selected for fast movement and multiplication within plants, which increase the likelihood of plant-to-plant transmission (70). Faster movement and multiplication within plants are correlated with virulence and aggressiveness (e.g., 41, 94, 95). Purifying selection in these environments might be a strong factor in reducing pathogen diversity.

In other words, as X. fastidiosa in crop systems becomes more adapted to a particular host species, it also becomes more aggressive because it spreads among hosts more efficiently (Figure 3). Such strong selection would purge less-fit genotypes from populations, leading to highly specialized pathogens. Here, HR events within populations would lead to reduced diversification, as replacing alleles would be similar. However, owing to sequence divergence and ecological isolation, HR events with unrelated genotypes are both rare and associated with genes that do not determine host specificity. Genes important for the colonization of individual host species (i.e., associated with host specificity) are likely recalcitrant to $\mathrm{HR}$, and a recipient bacterial strain is less fit, removed from the population, and therefore not detected. In summary, we propose that $X$. fastidiosa specialization in monoculture agricultural systems leads to more aggressive pathogen genotypes. We also postulate that such aggressiveness is maximized, and modulated, at a threshold point where the development of plant disease symptoms becomes incompatible with vector host preference behaviors as well as pathogen acquisition and consequently decreases rates of $X$. fastidiosa spread.

\section{DISEASE HARM TO AGROECOSYSTEM SERVICES}

$X$. fastidiosa emergence around the world and associated disease epidemics have generated widespread concern and controversy, owing in large part to effects on agroecosystems. Disease 
Natural environment

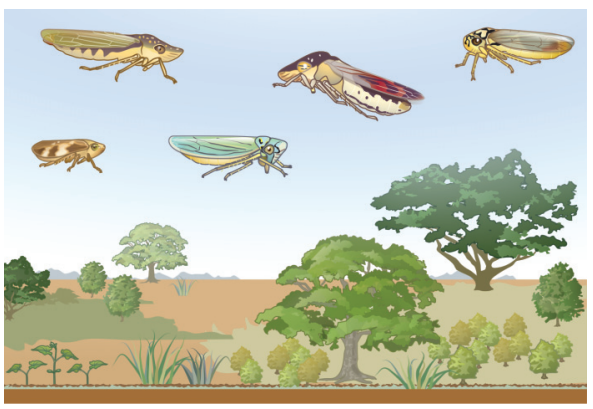

Agricultural environment

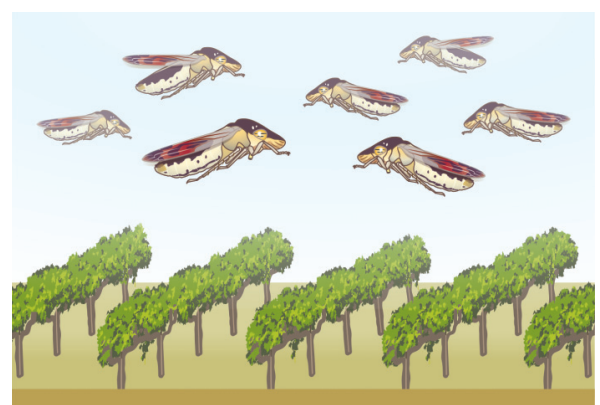

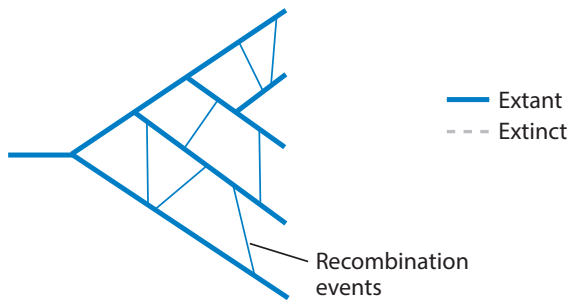

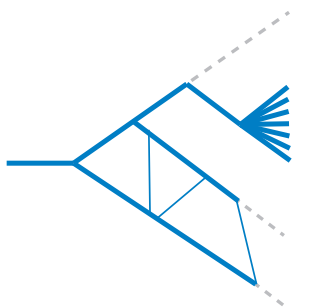

Iime

Time

Figure 2

Conceptual model of the ecological pressures on Xylella fastidiosa genetic diversity in natural and agricultural settings. In low-diversity crop systems, the pathogen may benefit from clonality and be under selection for more aggressive strains, which would have a higher likelihood of being disseminated from plant to plant. In diverse plant communities, species of polyphagous vectors would transmit strains to various host species; the ecological pressures selecting for a wide host range may limit pathogen virulence for a particular plant species. Accordingly, ecological isolation in agricultural environments may limit the frequency and/or impact of homologous recombination on genetic diversity, resulting in highly specialized $X$. fastidiosa genotypes.

epidemics caused by $X$. fastidiosa broadly harm the provisioning of agroecosystem services in two ways: by reducing crop yield and through nontarget effects from disease management (Figure 4). Complete economic accounting of yield losses from $X$. fastidios $a$-associated diseases is beyond the scope of this review and has rarely been undertaken. Tumber et al. (141) estimated that PD costs the California grape-growing industry US\$104 million per year in reduced yield, management costs, and regulatory costs. This does not include the fraught and difficult accounting of indirect losses due to disease, such as reduced ecosystem services.

The ways in which $X$. fastidiosa reduces agroecosystem services are socially contingent. Our review thus far has focused on the ecological and evolutionary drivers of disease emergence (e.g., host jumping, climate change, and pathogen introduction). However, disease emergence is only one of several events or conditions required for agroecosystem harm. How people and institutions respond to disease emergence mediate the agroecological consequences. This is a particularly difficult problem for $X$. fastidiosa diseases, a technically challenging organism to perform research on, as politically difficult decisions such as eradication efforts must be devised and implemented quickly with limited or incomplete information. For example, $X$. fastidios $a$ was associated with the olive decline disease in Italy in 2013 (129), but proof of causality was not published until 2017 (i.e., fulfillment of Koch's postulates) (127). 


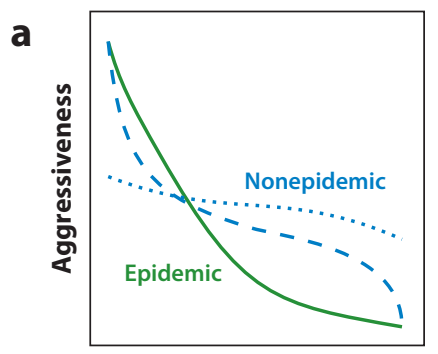

Host range breadth b

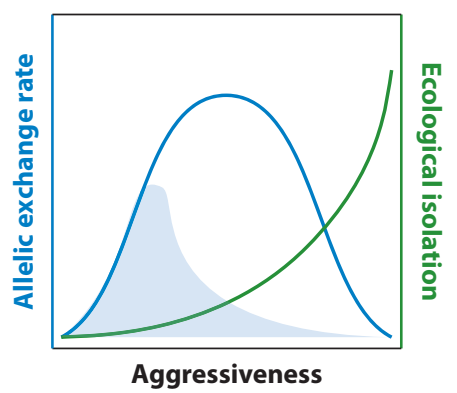

Figure 3

Hypothesized consequence of trade-offs between pathogen genotype aggressiveness and host range on recombination. (a) Epidemic Xylella fastidiosa genotypes (green line) may be highly aggressive to a few host plant species, with mean aggressiveness decreasing sharply as host-range breadth increases. Conversely, nonepidemic genotypes (blue lines) may behave more like generalist pathogens, that is, more aggressive but not necessarily pathogenic to a larger number of host plant species. Here, we present two scenarios: one in which the trade-off between aggressiveness and host breadth is strong (blue dashed line), and another in which it is much less so (blue dotted line). (b) Aggressiveness is expected to increase with ecological isolation (i.e., host specialization). As ecological isolation increases, $X$. fastidiosa genotypes encounter and exchange alleles with distinct genotypes less often. Host specialization, in turn, leads to purifying selection and sequence divergence, further reducing the frequency of recombination events. Yet strains that are not aggressive enough do not reach high populations in the landscape, regardless of host breadth, and they have limited opportunities to recombine. Therefore, the frequency of recombination events peaks at an intermediate stage in which ecological isolation is not complete. The shaded area under the allelic exchange rate illustrates the potential for exchange of loci associated with host specialization. These loci may be freely exchanged among isolates that are not host specific but would become recalcitrant to recombination once strains become isolated, as exchange with poorly adapted loci would lead to loss of fitness and purge from the population. Allelic exchange rate is used here as a measure of exchanges that lead to new allele sequences. Exchanges that would lead to the same sequence, which are expected to be common but are not detectable or likely to be ecologically important, are not included.

Reduced crop yield is, by definition, a result of ineffective management of a disease. Although yield loss is clearly difficult to prevent completely, lack of stakeholder cooperation or trust as well as the difficulties political institutions have in implementing required measures can exacerbate ineffective disease management. For example, conspiratorial and pseudoscientific theories on the establishment of $X$. fastidiosa-caused olive quick decline syndrome in southern Italy have persisted through online communication platforms and potentially hampered public support for robust management responses by the government (25). Importantly, lack of cooperation or trust among stakeholders can be exacerbated when management strategies are developed without adequate public deliberation or stakeholder buy-in; methods for building cooperation and trust among stakeholders have been outlined elsewhere (97).

Vector control, including the use of insecticides, may be a necessary and important response to any vector-borne disease, particularly in the early stages of an epidemic. However, even if vector control is effective, it may not always be needed or economically justified. For example, although imidacloprid application to grapevines in Southern California reduced PD incidence slightly when disease prevalence was not high, the cost of application was likely greater than any modest yield gains given the low disease pressure (37). In addition, populations of nontarget organisms may decline owing to insecticide use, with associated reductions in ecosystem services (20). These harms can be further exacerbated by ineffective use or overuse of insecticides; the latter may also lead to vector resistance to pesticides. In turn, the causes of insecticide overuse are not always straightforward; rather, social and economic forces, including technology diffusion and 


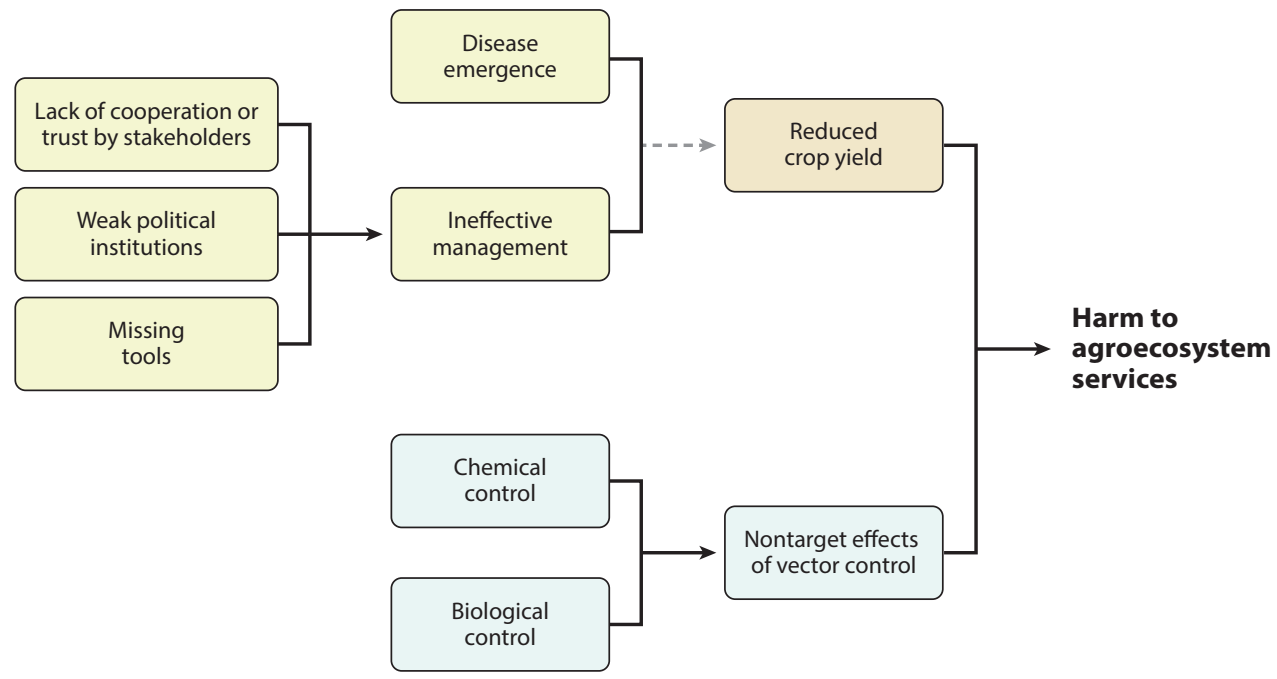

Figure 4

Risk assessment tree (inspired by fault tree analysis) illustrating processes leading to agroecosystem harm caused by Xylella fastidiosa diseases. Disease emergence is not the sole reason why X. fastidiosa presents a risk to landscapes, and a disease's impacts are mediated by the sociopolitical context. Disease emergence can only cause agroecosystem harm if management is ineffective. In turn, a lack of cooperation or trust by stakeholders, weak political institutions, or missing management tools (e.g., scientific uncertainty and lack of decision-making protocols) can all produce ineffective management. Disease management through vector suppression, using chemical or biological control, can produce harms independent of yield loss, such as nontarget effects. Processes preceded by a closed black arrow can occur through any of the preceding processes (i.e., an OR gate); processes preceded by a dashed grey arrow can occur only through the combination of all proceeding processes (an AND gate).

extension services, market forces, farmer demographics and knowledge, and political institutional constraints, mediate insecticide use (74). Finally, introduced biological control agents aimed at suppressing vector populations as well as new crop genotypes with novel resistance traits could also affect nontarget organisms. However, no evidence exists on the potential importance or prevalence of these impacts for $X$. fastidiosa.

\section{FINAL THOUGHTS}

Research on X. fastidios $a$ has been driven by disease epidemics, initially in the United States, then Brazil, and more recently Europe. Accordingly, knowledge has accumulated in leaps rather than incrementally and has focused on a combination of applied disease management priorities and technologies available to scientists. For example, the epidemics in Brazil and the United States at the end of the twentieth century took advantage of genomic tools and led to the development of a thriving community of researchers studying pathogen-plant-insect molecular interactions. However, because $X$. fastidiosa is endemic in the Americas, limited effort has been made to understand patterns of pathogen spread at large (i.e., regional or continental) scales. Similarly, the determinants of pathogen host specificity remain unknown, although this topic may benefit from European epidemics owing to its intrinsic importance for containment and quarantine efforts as well as the now-ubiquitous availability of genomic data.

Accordingly, we have considered X. fastidiosa disease emergence in a framework that generates testable hypotheses while identifying current gaps in knowledge or data availability. We are aware 
of and acknowledge the difficulty in predicting, for example, how climate change will impact disease prevalence but nevertheless raise points we expect to drive expansion or retraction of geographical ranges. As with many diseases, anthropogenic forces often feature prominently in emergence events of $X$. fastidiosa-associated diseases. Perhaps less clear, however, are the social, economic, and political conditions that mediate the consequences of disease emergence. Finally, we briefly highlight some ways in which the biological aspects of $X$. fastidiosa intersect with such anthropogenic forces to generate disease epidemics and agroecosystem risk. In summary, we hope this review serves as food for thought.

\section{DISCLOSURE STATEMENT}

The authors are not aware of any affiliations, memberships, funding, or financial holdings that might be perceived as affecting the objectivity of this review.

\section{ACKNOWLEDGMENTS}

We acknowledge the recent and ongoing support for our research on X. fastidiosa by the Pierce's Disease and Glassy-Winged Sharpshooter Board and the California Department of Food and Agriculture, the United States Department of Agriculture, the Horizon 2020 program of the European Commission (XF-ACTORS), and the University of California Division of Agriculture and Natural Resources. A.S. is currently supported by a Marie Skłodowska-Curie Fellowship (European Union's Horizon 2020 Research and Innovation Program, grant agreement 707013). Support by these agencies did not shape our questions or views. We thank and acknowledge Sandy Purcell, Bruce Kirkpatrick, and Steve Lindow for their influence on our thinking and desire to pursue research questions aimed at helping those affected by $X$. fastidiosa diseases. We also thank Christian Vernière and Philippe Roumagnac for their insightful comments on this review.

\section{LITERATURE CITED}

1. Aide TM, Grau HR. 2004. Globalization, migration, and Latin American ecosystems. Science 305:191516

2. Almeida RPP, Blua MJ, Lopes JRS, Purcell AH. 2005. Vector transmission of Xylella fastidiosa: applying fundamental knowledge to generate disease management strategies. Ann. Entomol. Soc. Am. 98:775-86

3. Almeida RPP, Nascimento FE, Chau J, Prado SS, Tsai C-W, et al. 2008. Genetic structure and biology of Xylella fastidiosa strains causing disease in citrus and coffee in Brazil. Appl. Environ. Microbiol. 74:3690-701

4. Almeida RPP, Nunney L. 2015. How do plant diseases caused by Xylella fastidiosa emerge? Plant Dis. 99:1457-67

5. Almeida RPP, Purcell AH. 2003. Transmission of Xylella fastidiosa to grapevines by Homalodisca coagulata (Hemiptera: Cicadellidae). 7. Econ. Entomol. 96:264-71

6. Almeida RPP, Purcell AH. 2006. Patterns of Xylella fastidiosa colonization on the precibarium of sharpshooter vectors relative to transmission to plants. Ann. Entomol. Soc. Am. 99:884-90

7. Andersen PC, Brodbeck BV, Mizell RF. 1992. Feeding by the leafhopper, Homalodisca coagulata, in relation to xylem fluid chemistry and tension. F. Insect Physiol. 38:611-22

8. Anderson PK, Cunningham AA, Patel NG, Morales FJ, Epstein PR, Daszak P. 2004. Emerging infectious diseases of plants: pathogen pollution, climate change and agrotechnology drivers. Trends Ecol. Evol. 19:535-44

9. Auricoste J, Claquin P, Denancé N, Jacques M-A, de Jerphanion P, et al. 2017. Xylella fastidiosa en Francia en ornamentales y otras especies. See Ref. 82, pp. 211-29

10. Baccari C, Lindow SE. 2011. Assessment of the process of movement of Xylella fastidiosa within susceptible and resistant grape cultivars. Phytopathology 101:77-84 
11. Benning TL, LaPointe D, Atkinson CT, Vitousek PM. 2002. Interactions of climate change with biological invasions and land use in the Hawaiian Islands: modeling the fate of endemic birds using a geographic information system. PNAS 99:14246-49

12. Bergsma-Vlami M, van de Bilt JLJ, Tjou-Tam-Sin NNA, Helderman CM, Gorkink-Smits PPMA, et al. 2017. Assessment of the genetic diversity of Xylella fastidiosa in imported ornamental Coffea arabica plants. Plant Pathol. 66:1065-74

13. Blua MJ, Morgan DJW. 2003. Dispersion of Homalodisca coagulata (Hemiptera: Cicadellidae), a vector of Xylella fastidiosa, into vineyards in southern California. 7. Econ. Entomol. 96:1369-74

14. Blua MJ, Phillips PA, Redak RA. 1999. A new sharpshooter threatens both crops and ornamentals. Calif. Agric. 53:22-25

15. Bosso L, Di Febbraro M, Cristinzio G, Zoina A, Russo D. 2016. Shedding light on the effects of climate change on the potential distribution of Xylella fastidiosa in the Mediterranean basin. Biol. Invasions 18:1759-68

16. Bosso L, Russo D, Di Febbraro M, Cristinzio G, Zoina A. 2016. Potential distribution of Xylella fastidiosa in Italy: a maximum entropy model. Phytopathol. Mediterr. 55:62-72

17. Brlansky RH. 1983. Colonization of the sharpshooter vectors, Oncometopia nigricans and Homalodisca coagulata, by xylem-limited bacteria. Pbytopathology 73:530-35

18. Browning JA, Frey KJ. 1969. Multiline cultivars as a means of disease control. Annu. Rev. Phytopathol. 7:355-82

19. Burbank LP, Van Horn CR. 2017. Conjugative plasmid transfer in Xylella fastidiosa is dependent on tra and trb operon functions. F. Bacteriol. 199:e00388-17

20. Chagnon M, Kreutzweiser D, Mitchell EAD, Morrissey CA, Noome DA, Van der Sluijs JP. 2015. Risks of large-scale use of systemic insecticides to ecosystem functioning and services. Environ. Sci. Pollut. Res. Int. 22(1):119-34

21. Chang CJ, Garnier M, Zreik L, Rossetti V, Bové JM. 1993. Culture and serological detection of the xylem-limited bacterium causing citrus variegated chlorosis and its identification as a strain of Xylella fastidiosa. Curr. Microbiol. 27:137-42

22. Chatterjee S, Wistrom C, Lindow SE. 2008. A cell-cell signaling sensor is required for virulence and insect transmission of Xylella fastidiosa. PNAS 105:2670-75

23. Chen J, Groves R, Civerolo EL, Viveros M, Freeman M, Zheng Y. 2005. Two Xylella fastidiosa genotypes associated with almond leaf scorch disease on the same location in California. Phytopathology 95:708-14

24. Cohan FM, Koeppel AF. 2008. The origins of ecological diversity in prokaryotes. Curr. Biol. 18:R102434

25. Colella C. 2016. Distrusting science on communication platforms: socio-anthropological aspects of the science-society dialectic within a phytosanitary emergency. In Proceedings of the 2 nd International Workshop on Social Media World Sensors, 10th International Conference on Language Resources and Evaluation, ed. L Di Caro, M Cataldi, C Schifanella, pp. 19-24. Portoroz, Slovenia: Eur. Lang. Res. Assoc.

26. Coletta-Filho HD, Francisco CS, Almeida RPP. 2014. Temporal and spatial scaling of the genetic structure of a vector-borne plant pathogen. Phytopatbology 104:120-25

27. Coletta-Filho HD, Francisco CS, Lopes JRS, De Oliveira AF, Da Silva LFDO. 2016. First report of olive leaf scorch in Brazil, associated with Xylella fastidiosa subsp. pauca. Phytopathol. Mediterr. 55:130

28. Coletta-Filho HD, Francisco CS, Lopes JRS, Muller C, Almeida RPP. 2017. Homologous recombination and Xylella fastidiosa host-pathogen associations in South America. Phytopathology 107:305-12

29. Cornara D, Cavalieri V, Dongiovanni C, Altamura G, Palmisano F, et al. 2017. Transmission of Xylella fastidiosa by naturally infected Philaenus spumarius (Hemiptera, Aphrophoridae) to different host plants. 7. Appl. Entomol. 141:80-87

30. Cornara D, Sicard A, Zeilinger AR, Porcelli F, Purcell AH, Almeida RPP. 2016. Transmission of Xylella fastidiosa to grapevine by the meadow spittlebug. Phytopathology 106:1285-90

31. Costa HS, Guzman A, Hernandez-Martinez R, Gispert C, Cooksey DA. 2006. Detection and differentiation of Xylella fastidiosa strains acquired and retained by glassy-winged sharpshooters (Hemiptera: Cicadellidae) using a mixture of strain-specific primer sets. 7. Econ. Entomol. 99:1058-64

32. Crowl TA, Crist TO, Parmenter RR, Belovsky G, Lugo AE. 2008. The spread of invasive species and infectious disease as drivers of ecosystem change. Front. Ecol. Environ. 6:238-46 
33. Cryan JR, Svenson GJ. 2010. Family-level relationships of the spittlebugs and froghoppers (Hemiptera: Cicadomorpha: Cercopoidea). Syst. Entomol. 35:393-415

34. Daugherty MP, Almeida RPP. 2009. Estimating Xylella fastidiosa transmission parameters: decoupling sharpshooter number and feeding period. Entomol. Exp. Appl. 132:84-92

35. Daugherty MP, Bosco D, Almeida RPP. 2009. Temperature mediates vector transmission efficiency: inoculum supply and plant infection dynamics. Ann. Appl. Biol. 155:361-69

36. Daugherty MP, Lopes J, Almeida RPP. 2010. Vector within-host feeding preference mediates transmission of a heterogeneously distributed pathogen. Ecol. Entomol. 35:360-66

37. Daugherty MP, O’Neill S, Byrne F, Zeilinger AR. 2015. Is vector control sufficient to limit pathogen spread in vineyards? Environ. Entomol. 44:789-97

38. Daugherty MP, Rashed A, Almeida RPP, Perring TM. 2011. Vector preference for hosts differing in infection status: sharpshooter movement and Xylella fastidiosa transmission. Ecol. Entomol. 36:654-62

39. Daugherty MP, Zeilinger AR, Almeida RPP. 2017. Conflicting effects of climate and vector behavior on the spread of a plant pathogen. Phytobiomes 1:46-53

40. Davis MJ, Purcell AH, Thomson SV. 1978. Pierce's disease of grapevines: isolation of the causal bacterium. Science 199:75-77

41. De La Fuente L, Burr TJ, Hoch HC. 2007. Mutations in type I and type IV pilus biosynthetic genes affect twitching motility rates in Xylella fastidiosa. F. Bacteriol. 189:7507-10

42. De La Fuente L, Chacón-Diaz C, Almeida RPP. 2017. Enfermedades causadas por Xylella fastidiosa en Estados Unidos y Costa Rica. See Ref. 82, pp. 149-76

43. de Mello Varani A, Souza RC, Nakaya HI, de Lima WC, Paula de Almeida LG, et al. 2008. Origins of the Xylella fastidiosa prophage-like regions and their impact in genome differentiation. PLOS ONE 3:e4059

44. Denancé N, Legendre B, Briand M, Olivier V, de Boisseson C, et al. 2017. Several subspecies and sequence types are associated with the emergence of Xylella fastidiosa in natural settings in France. Plant Pathol. 66:1054-64

45. Dileone JA, Mundt CC. 1994. Effect of wheat cultivar mixtures on populations of Puccinia striiformis races. Plant Pathol. 43:917-30

46. Dionisio F, Conceição IC, Marques ACR, Fernandes L, Gordo I. 2005. The evolution of a conjugative plasmid and its ability to increase bacterial fitness. Biol. Lett. 1:250-52

47. Doddapaneni H, Francis M, Yao J, Lin H, Civerolo EL. 2007. Genome-wide analysis of Xylella fastidiosa: implications for detection and strain relationships. Afr. F. Biotechnol. 6:055-066

48. Doddapaneni H, Yao J, Lin H, Walker MA, Civerolo EL. 2006. Analysis of the genome-wide variations among multiple strains of the plant pathogenic bacterium Xylella fastidiosa. BMC Genom. 7:225

49. Dukes JS, Mooney HA. 1999. Does global change increase the success of biological invaders? Trends Ecol. Evol. 14:135-39

50. Panel Plant Health EFSA. 2015. Scientific opinion on the risks to plant health posed by Xylella fastidiosa in the EU territory, with the identification and evaluation of risk reduction options. EFSA F. 13:3989

51. Elena SF, Fraile A, Garcia-Arenal F. 2014. Evolution and emergence of plant viruses. Adv. Virus Res. $88: 161-91$

52. Eur. Food Saf. Auth. 2016. Update of a database of host plants of Xylella fastidiosa: 20 November 2015. EFSA 7. 14:4378

53. Feil H, Feil WS, Purcell AH. 2003. Effects of date of inoculation on the within-plant movement of Xylella fastidiosa and persistence of Pierce's disease within field grapevines. Phytopathology 93:244-51

54. Feil H, Purcell AH. 2001. Temperature-dependent growth and survival of Xylella fastidiosa in vitro and in potted grapevines. Plant Dis. 85:1230-34

55. Fernández-López R, Garcillán-Barcia MP, Revilla C, Lázaro M, Vielva L, de la Cruz F. 2006. Dynamics of the IncW genetic backbone imply general trends in conjugative plasmid evolution. FEMS Microbiol. Rev. 30:942-66

56. Francisco CS, Ceresini PC, Almeida RPP, Coletta-Filho HD. 2017. Spatial genetic structure of coffeeassociated Xylella fastidiosa populations indicates that cross infection does not occur with sympatric citrus orchards. Phytopathology 107:395-402 
57. Frazier NW. 1965. Xylem viruses and their insect vectors. In Proceedings of the International Conference on Virus and Vector on Perennial Hosts, with Special Reference to Vitis, ed. WB Hewitt, pp. 91-99. Davis, CA: Div. Agric. Sci. Univ. Calif.

58. Freitag JH. 1951. Host range of the Pierce's disease virus of grapes as determined by insect transmission. Phytopathology 41:920-34

59. Garrett KA, Dendy SP, Frank EE, Rouse MN, Travers SE. 2006. Climate change effects on plant disease: genomes to ecosystems. Annu. Rev. Phytopathol. 44:489-509

60. Giampetruzzi A, Saponari M, Loconsole G, Boscia D, Savino VN, et al. 2017. Genome-wide analysis provides evidence on the genetic relatedness of the emergent Xylella fastidiosa genotype in Italy to isolates from Central America. Phytopathology 107:816-27

61. Gruber BR, Daugherty MP. 2013. Understanding the effects of multiple sources of seasonality on the risk of pathogen spread to vineyards: vector pressure, natural infectivity, and host recovery. Plant Pathol. 62:194-204

62. Haelterman RM, Tolocka PA, Roca ME, Guzmán FA, Fernández FD, Otero ML. 2015. First presumptive diagnosis of Xylella fastidiosa causing olive scorch in Argentina. 7. Plant Pathol. 97:393

63. Harris JL, Balci Y. 2015. Population structure of the bacterial pathogen Xylella fastidiosa among street trees in Washington D.C. PLOS ONE 10:e0121297

64. Hartung JS. 1994. Citrus variegated chlorosis bacterium: axenic culture, pathogenicity, and serological relationships with other strains of Xylella fastidiosa. Phytopathology 84:591-97

65. Harvell CD. 2002. Climate warming and disease risks for terrestrial and marine biota. Science 296:215862

66. Hendson M, Purcell AH, Chen D, Smart C, Guilhabert M, Kirkpatrick B. 2001. Genetic diversity of Pierce's disease strains and other pathotypes of Xylella fastidiosa. Appl. Environ. Microbiol. 67:895-903

67. Hewitt WB, Frazier NW, Freitag JH, Winkler AJ. 1949. Pierce's disease investigations. Hilgardia 19:207-64

68. Hewitt WB, Houston B, Frazier NW, Freitag JH. 1946. Leafhopper transmission of the virus causing Pierce's disease of grape and dwarf of alfalfa. Phytopathology 36:117-28

69. Hill BL, Purcell AH. 1995. Acquisition and retention of Xylella fastidiosa by an efficient vector. Graphocephala atropunctata. Phytopathology 85:209-12

70. Hill BL, Purcell AH. 1997. Populations of Xylella fastidiosa in plants required for transmission by an efficient vector. Phytopathology 87:1197-201

71. Hoddle MS. 2004. The potential adventive geographic range of glassy-winged sharpshooter, Homalodisca coagulata and the grape pathogen Xylella fastidiosa: implications for California and other grape growing regions of the world. Crop Prot. 23:691-99

72. Houghton JT, Ding Y, Griggs DJ, Noguer M, van der Linden PJ, et al. 2001. Climate Change 2001: The Scientific Basis. Contribution of Working Group I to the Third Assessment Report of the Intergovernmental Panel on Climate Change. New York: Cambridge Univ. Press

73. Jacques M-A, Denancé N, Legendre B, Morel E, Briand M, et al. 2016. New coffee plant-infecting Xylella fastidiosa variants derived via homologous recombination. Appl. Environ. Microbiol. 82:1556-68

74. Jin S, Bluemling B, Mol APJ. 2015. Information, trust and pesticide overuse: interactions between retailers and cotton farmers in China. NFAS 72-73:23-32

75. Kandel PP, Almeida RPP, Cobine PA, De La Fuente L. 2017. Natural competence rates are variable among Xylella fastidiosa strains and homologous recombination occurs in vitro between subspecies fastidiosa and multiplex. Mol. Plant-Microbe Interact. 30:589-600

76. Killiny N, Almeida RPP. 2009. Xylella fastidiosa afimbrial adhesins mediate cell transmission to plants by leafhopper vectors. Appl. Environ. Microbiol. 75:521-28

77. Krell RK, Boyd EA, Nay JE, Park YL, Perring TM. 2007. Mechanical and insect transmission of Xylella fastiosa to Vitis vinifera. Am. 7. Enol. Vitic. 58:211-16

78. Krugner R, Hagler JR, Groves RL, Sisterson MS, Morse JG, Johnson MW. 2012. Plant water stress effects on the net dispersal rate of the insect vector Homalodisca vitripennis (Hemiptera: Cicadellidae) and movement of its egg parasitoid, Gonatocerus ashmeadi (Hymenoptera: Mymaridae). Environ. Entomol. 41:1279-89 
79. Kung SH, Almeida RPP. 2011. Natural competence and recombination in the plant pathogen Xylella fastidiosa. Appl. Environ. Microbiol. 77:5278-84

80. Kung SH, Retchless AC, Kwan JY, Almeida RPP. 2013. Effects of DNA size on transformation and recombination efficiencies in Xylella fastidiosa. Appl. Environ. Microbiol. 79:1712-17

81. Labroussaa F, Ionescu M, Zeilinger AR, Lindow SE, Almeida RPP. 2017. A chitinase is required for Xylella fastidiosa colonization of its insect and plant hosts. Microbiology 163:502-9

82. Landa BB, Marco-Noales E, Milagros López M, eds. 2017. Enfermedades Causadas por la Bacteria Xylella fastidiosa. Almeria, Spain: Cajamar Caja Rural

83. Laranjeira FF, Bergamin Filho A, Amorim L, Berger R, Gottwald TR. 2003. Dinâmica temporal da Clorose Variegada dos Citros em três regiões do Estado de São Paulo. Fitopatol. Bras. 28:481-88

84. Ledbetter CA, Chen J, Livingston S, Groves RL. 2009. Winter curing of Prunus dulcis cv 'Butte,' P. webbii and their interspecific hybrid in response to Xylella fastidiosa infections. Euphytica 169:113-22

85. Lei BR, Olival KJ. 2014. Contrasting patterns in mammal-bacteria coevolution: Bartonella and Leptospira in bats and rodents. PLOS Negl. Trop. Dis. 8:e2738

86. Lieth JH, Meyer MM, Yeo K-H, Kirkpatrick BC. 2011. Modeling cold curing of Pierce's disease in Vitis vinifera 'Pinot Noir' and 'Cabernet Sauvignon' grapevines in California. Phytopathology 101:1492-500

87. Loconsole G, Saponari M, Boscia D, D'Attoma G, Morelli M, et al. 2016. Intercepted isolates of Xylella fastidiosa in Europe reveal novel genetic diversity. Eur. F. Plant Pathol. 146:85-94

88. Lopes JRS, Daugherty MP, Almeida RPP. 2009. Context-dependent transmission of a generalist plant pathogen: host species and pathogen strain mediate insect vector competence. Entomol. Exp. Appl. $131: 216-24$

89. Marcelletti S, Scortichini M. 2016. Genome-wide comparison and taxonomic relatedness of multiple Xylella fastidiosa strains reveal the occurrence of three subspecies and a new Xylella species. Arch. Microbiol. 198:803-12

90. Marcelletti S, Scortichini M. 2016. Xylella fastidiosa CoDiRO strain associated with the olive quick decline syndrome in southern Italy belongs to a clonal complex of the subspecies pauca that evolved in Central America. Microbiology 162:2087-98

91. Martelli GP. 2016. The current status of the quick decline syndrome of olive in southern Italy. Phytoparasitica $44: 1-10$

92. Marucci RC, Lopes JRS, Vendramim JD, Corrente JE. 2005. Influence of Xylella fastidiosa infection of citrus on host selection by leafhopper vectors. Entomol. Exp. Appl. 117:95-103

93. McElrone AJ, Sherald JL, Forseth IN. 2001. Effects of water stress on symptomatology and growth of Parthenocissus quinquefolia infected by Xylella fastidiosa. Plant Dis. 85:1160-64

94. Meng Y, Li Y, Galvani CD, Hao G, Turner JN, et al. 2005. Upstream migration of Xylella fastidiosa via pilus-driven twitching motility. 7. Bacteriol. 187:5560-67

95. Newman KL, Almeida RPP, Purcell AH, Lindow SE. 2003. Use of a green fluorescent strain for analysis of Xylella fastidiosa colonization of Vitis vinifera. Appl. Environ. Microbiol. 69:7319-27

96. Newman KL, Almeida RPP, Purcell AH, Lindow SE. 2004. Cell-cell signaling controls Xylella fastidiosa interactions with both insects and plants. PNAS 101:1737-42

97. Natl. Res. Council. 1996. Understanding Risk: Informing Decisions in a Democratic Society. Washington, DC: Natl. Acad. Press

98. Nunes LR, Rosato YB, Muto NH, Yanai GM, da Silva VS, et al. 2003. Microarray analyses of Xylella fastidiosa provide evidence of coordinated transcription control of laterally transferred elements. Genome Res. 13:570-78

99. Nunney L, Hopkins DL, Morano LD, Russell SE, Stouthamer R. 2014. Intersubspecific recombination in Xylella fastidiosa strains native to the United States: infection of novel hosts associated with an unsuccessful invasion. Appl. Environ. Microbiol. 80:1159-69

100. Nunney L, Schuenzel EL, Scally M, Bromley RE, Stouthamer R. 2014. Large-scale intersubspecific recombination in the plant-pathogenic bacterium Xylella fastidiosa is associated with the host shift to mulberry. Appl. Environ. Microbiol. 80:3025-33

101. Nunney L, Vickerman DB, Bromley RE, Russell SA, Hartman JR, et al. 2013. Recent evolutionary radiation and host plant specialization in the Xylella fastidiosa subspecies native to the United States. Appl. Environ. Microbiol. 79:2189-200 
102. Nunney L, Yuan X, Bromley R, Hartung J, Montero-Astúa M, et al. 2010. Population genomic analysis of a bacterial plant pathogen: novel insight into the origin of Pierce's disease of grapevine in the U.S. PLOS ONE 5:e15488

103. Nunney L, Yuan X, Bromley RE, Stouthamer R. 2012. Detecting genetic introgression: high levels of intersubspecific recombination found in Xylella fastidiosa in Brazil. Appl. Environ. Microbiol. 78:4702-14

104. Olmo D, Nieto A, Adrover F, Urbano A, Beidas O, et al. 2017. First detection of Xylella fastidiosa infecting cherry (Prunus avium) and Polygala myrtifolia plants, in Mallorca Island, Spain. Plant Dis. 101:1820

105. Olmo D, Nieto A, Borràs D, Montesinos M, Adrover F, et al. 2017. X. fastidiosa en las Islas Baleares. See Ref. 82, pp. 231-61

106. Paião FG, Meneguim AA, Casagrande EC, Leite RP Jr. 2002. Envolvimento de cigarras (Homoptera, Cicadidae) na transmissão de Xylella fastidiosa em cafeeiro. Fitopatol. Bras. 27:67

107. Parker IM, Saunders M, Bontrager M, Weitz AP, Hendricks R, et al. 2015. Phylogenetic structure and host abundance drive disease pressure in communities. Nature 520:542-44

108. Parry M, Gibson GJ, Parnell S, Gottwald TR, Irey MS, et al. 2014. Bayesian inference for an emerging arboreal epidemic in the presence of control. PNAS 111:6258-62

109. Patz JA, Daszak P, Tabor GM, Aguirre AA, Pearl M, et al. 2004. Unhealthy landscapes: policy recommendations on land use change and infectious disease emergence. Environ. Health Perspect. 112:1092-98

110. Perring TM, Farrar CA, Blua MJ. 2001. Proximity to citrus influences Pierce's disease in Temecula Valley vineyards. Calif. Agric. 55:13-18

111. Pierce NB. 1892. The California Vine Disease: A Preliminary Report of Investigations. Washington, DC: Gov. Print. Off.

112. Potere O, Susca L, Loconsole G, Saponari M, Boscia D, et al. 2015. Survey for the presence of Xylella fastidiosa subsp. pauca strain CoDiRO in some forestry and ornamental species in the Salento peninsula. 7. Plant Pathol. 97:373-76

113. Purcell A. 1982. Pierce's disease: progress and prognosis. Dev. Ind. Microbiol. 23:99-105

114. Purcell A. 1997. Xylella fastidiosa, a regional problem or global threat? F. Plant Pathol. 79:99-105

115. Purcell A. 2013. Paradigms: examples from the bacterium Xylella fastidiosa. Annu. Rev. Phytopathol. 51:33956

116. Purcell AH. 1977. Cold therapy of Pierce's disease grapevines. Plant Dis. Rep. 61:514-18

117. Purcell AH, Finlay AH. 1979. Evidence for noncirculative transmission of Pierce's disease bacterium by sharpshooter leafhoppers. Phytopathology 69:393-95

118. Purcell AH, Finlay AH, McLean DL. 1979. Pierce's disease bacterium: mechanism of transmission by leafhopper vectors. Science 206:839-41

119. Purcell AH, Saunders SR. 1999. Fate of Pierce's disease strains of Xylella fastidiosa in common riparian plants in California. Plant Dis. 83:825-30

120. Rashed A, Killiny N, Kwan J, Almeida RPP. 2011. Background matching behaviour and pathogen acquisition: plant site preference does not predict the bacterial acquisition efficiency of vectors. ArthropodPlant Interact. 5:97-106

121. Redak RA, Purcell AH, Lopes JRS, Blua MJ, Mizell RF III, Andersen PC. 2004. The biology of xylemfluid insect vectors of Xylella fastidiosa and their relation to disease epidemiology. Annu. Rev. Entomol. 49:243-70

122. Retchless AC, Labroussaa F, Shapiro L, Stenger DC, Lindow SE, Almeida RPP. 2014. Genomic insights into Xylella fastidiosa interactions with plant and insect hosts. In Genomics of Plant-Associated Bacteria, ed. DC Gross, A Lichens-Park, C Kole, pp. 177-202. Berlin/Heidelberg: Springer

123. Rogers EE, Stenger DC. 2012. A conjugative $38 \mathrm{kB}$ plasmid is present in multiple subspecies of Xylella fastidiosa. PLOS ONE 7:e52131

124. Roselló M, Ferrer A, Peris-Peris C, Llopis JM, Rallo E, et al. 2017. Xylella fastidiosa en la comunidad Valenciana. See Ref. 82, pp. 263-76

125. Rosenzweig C, Iglesias A, Yang XB, Epstein PR, Chivian E. 2001. Climate change and extreme weather events; implications for food production, plant diseases, and pests. Glob. Change Hum. Health 2:90-104

126. Sakai AK, Allendorf FW, Holt JS, Lodge DM, Molofsky J, et al. 2001. The population biology of invasive species. Anпu. Rev. Ecol. Syst. 32:305-32 
127. Saponari M, Boscia D, Altamura G, Loconsole G, Zicca S, et al. 2017. Isolation and pathogenicity of Xylella fastidiosa associated to the olive quick decline syndrome in southern Italy. Sci. Rep. 7:17723

128. Saponari M, Boscia D, Loconsole G, Palmisano F, Savino V, et al. 2014. New hosts of Xylella fastidiosa strain CoDiRO in Apulia. F. Plant Patbol. 96:603-11

129. Saponari M, Boscia D, Nigro F, Martelli GP. 2013. Identification of DNA sequences related to Xylella fastidiosa in oleander, almond and olive trees exhibiting leaf scorch symptoms in Apulia (southern Italy). 7. Plant Pathol. 95:668

130. Scally M, Schuenzel EL, Stouthamer R, Nunney L. 2005. Multilocus sequence type system for the plant pathogen Xylella fastidiosa and relative contributions of recombination and point mutation to clonal diversity. Appl. Environ. Microbiol. 71:8491-99

131. Severin HHP. 1950. Spittle-insect vectors of Pierce's disease virus: II. Life history and virus transmission. Hilgardia 19:357-82

132. Simpson AJG, Reinach FC, Arruda P, Abreu FA, Acencio M, et al. 2000. The genome sequence of the plant pathogen Xylella fastidiosa. Nature 406:151-57

133. Sisterson MS, Thammiraju SR, Lynn-Patterson K, Groves RL, Daane KM. 2010. Epidemiology of diseases caused by Xylella fastidiosa in California: evaluation of alfalfa as a source of vectors and inocula. Plant Dis. 94:827-34

134. Smith KF, Sax DF, Gaines SD, Guernier V, Guégan J-F. 2007. Globalization of human infectious disease. Ecology 88:1903-10

135. Son Y, Groves RL, Daane KM, Morgan DJW, Johnson MW. 2009. Influences of temperature on Homalodisca vitripennis (Hemiptera: Cicadellidae) survival under various feeding conditions. Environ. Entomol. 38:1485-95

136. Son Y, Groves RL, Daane KM, Morgan DJW, Krugner R, Johnson MW. 2010. Estimation of feeding threshold for Homalodisca vitripennis (Hemiptera: Cicadellidae) and its application to prediction of overwintering mortality. Environ. Entomol. 39:1264-75

137. Sorensen JT, Gill RJ. 1996. A range extension of Homalodisca coagulata (Say) (Hemiptera: Clypeorrhyncha: Cicadellidae) to southern California. Pan-Pac. Entomol. 72:160-61

138. Stearns SC. 1999. Evolution in Health and Disease. New York: Oxford Univ. Press

139. Stukenbrock EH, McDonald BA. 2008. The origins of plant pathogens in agro-ecosystems. Annu. Rev. Phytopathol. 46:75-100

140. Su C-C, Chang C-J, Chang C-M, Shih H-T, Tzeng K-C, et al. 2013. Pierce's disease of grapevines in Taiwan: isolation, cultivation and pathogenicity of Xylella fastidiosa. F. Phytopathol. 161:389-96

141. Tumber KP, Alston JM, Fuller KB. 2014. Pierce's disease costs California \$104 million per year. Calif. Agric. 68:20-29

142. Van Sluys MA, de Oliveira MC, Monteiro-Vitorello CB, Miyaki CY, Furlan LR, et al. 2003. Comparative analyses of the complete genome sequences of Pierce's disease and citrus variegated chlorosis strains of Xylella fastidiosa. 7. Bacteriol. 185:1018-26

143. Wells JM, Raju BC, Hung H-Y, Weisburg WG, Mandelco-Paul L, Brenner DJ. 1987. Xylella fastidiosa gen. nov., sp. nov: gram-negative, xylem-limited, fastidious plant bacteria related to Xanthomonas spp. Int. 7. Syst. Bacteriol. 37:136-43

144. White MA, Diffenbaugh NS, Jones GV, Pal JS, Giorgi F. 2006. Extreme heat reduces and shifts United States premium wine production in the 21st century. PNAS 103:11217-22

145. Wolfe MS. 1985. The current status and prospects of multiline cultivars and variety mixtures for disease resistance. Annu. Rev. Phytopathol. 23:251-73

146. Woolhouse MEJ, Haydon DT, Antia R. 2005. Emerging pathogens: the epidemiology and evolution of species jumps. Trends Ecol. Evol. 20:238-44

147. Woolhouse MEJ, Webster JP, Domingo E, Charlesworth B, Levin BR. 2002. Biological and biomedical implications of the co-evolution of pathogens and their hosts. Nat. Genet. 32:569-77

148. Yuan X, Morano L, Bromley R, Spring-Pearson S, Stouthamer R, Nunney L. 2010. Multilocus sequence typing of Xylella fastidiosa causing Pierce's disease and oleander leaf scorch in the United States. Phytopatbology 100:601-11

149. Zhu Y, Chen H, Fan J, Wang Y, Li Y, et al. 2000. Genetic diversity and disease control in rice. Nature 406:718-22 


\section{钑}

Annual Review of Phytopathology

Volume 56, 2018

Organic Amendments, Beneficial Microbes, and Soil Microbiota:

Toward a Unified Framework for Disease Suppression

Giuliano Bonanomi, Matteo Lorito, Francesco Vinale, and Sheridan L. Woo ............ 1

The Genome Biology of Effector Gene Evolution in Filamentous

Plant Pathogens

Andrea Sánchez-Vallet, Simone Fouché, Isabelle Fudal, Fanny E. Hartmann, Fessica L. Soyer, Aurélien Tellier, and Daniel Croll....

Seeing the Light: The Roles of Red- and Blue-Light Sensing in Plant Microbes

Gwyn A. Beattie, Bridget M. Hatfield, Haili Dong, and Regina S. McGrane

Advances in Wheat and Pathogen Genomics: Implications

for Disease Control

Beat Keller, Thomas Wicker, and Simon G. Krattinger

Joining the Crowd: Integrating Plant Virus Proteins into the Larger

World of Pathogen Effectors

Scott M. Leisner and Fames E. Schoelz....

The Future of Nanotechnology in Plant Pathology

Wade Elmer and Fason C. White

Mechanisms Underlying Establishment of Arbuscular

Mycorrhizal Symbioses

Jeongmin Choi, William Summers, and Uta Paszkowski

Antibiotic Resistance in Plant-Pathogenic Bacteria

George W. Sundin and Nian Wang

Xylella fastidiosa: Insights into an Emerging Plant Pathogen

Anne Sicard, Adam R. Zeilinger, Mathieu Vanhove, Tyler E. Schartel,

Dylan 7. Beal, Matthew P. Daugherty, and Rodrigo P.P. Almeida

The Barberry Eradication Program in Minnesota for Stem Rust

Control: A Case Study

Paul D. Peterson 
Endosymbionts of Plant-Parasitic Nematodes

Amanda M.V. Brown ....

Structural, Functional, and Genomic Diversity of Plant NLR Proteins:

An Evolved Resource for Rational Engineering of Plant Immunity

Freddy Monteiro and Marc T. Nishimura

The Changing Face of Bacterial Soft-Rot Diseases

Amy O. Charkowski

Biology of Fungi and Their Bacterial Endosymbionts

Teresa E. Pawlowska, Maria L. Gaspar, Olga A. Lastovetsky,

Stephen 7. Mondo, Imperio Real-Ramirez, Evaniya Shakya,

and Paola Bonfante...

Sclerotinia sclerotiorum: An Evaluation of Virulence Theories

Liangsheng Xu, Guoqing Li, Daohong Fiang, and Weidong Chen ...

Fitness Penalties in the Evolution of Fungicide Resistance

N.F. Hawkins and B.A. Fraaije

Multifaceted Impacts of Bacteriophages in the Plant Microbiome

Britt Koskella and Tiffany B. Taylor

Plant-Parasitic Nematodes and Food Security in Sub-Saharan Africa

Danny L. Coyne, Laura Cortada, Fobnathan 7. Dalzell,

Abiodun O. Claudius-Cole, Solveig Haukeland, Nessie Luambano,

and Herbert Talwana

The Rise and Rise of Nicotiana benthamiana: A Plant for All Reasons

Fulia Bally, Hyungtaek Jung, Cara Mortimer, Fatima Naim, Joshua G. Philips, Roger Hellens, Aureliano Bombarely, Michael M. Goodin, and Peter $M$. Waterhouse

Wheat Blast: Past, Present, and Future

Paulo Cezar Ceresini, Vanina Lilián Castroagudín, Fabrício Ávila Rodrigues,

Fonas Alberto Rios, Carlos Eduardo Aucique-Pérez, Silvino Intra Moreira,

Eduardo Alves, Daniel Croll, and Foão Leodato Nunes Maciel

Lessons from the Incursion of Myrtle Rust in Australia

Angus 7. Carnegie and Geoff S. Pegg

CRISPR Crops: Plant Genome Editing Toward Disease Resistance

Thorsten Langner, Sophien Kamoun, and Khaoula Belhaj

Understanding Cytoskeletal Dynamics During the Plant

Immune Response

Fiejie Li and Christopher 7. Staiger 
Hyperspectral Sensors and Imaging Technologies in Phytopathology:

State of the Art

A.-K. Mablein, M.T. Kuska, F. Bebmann, G. Polder, and A. Walter...

Network Analysis: A Systems Framework to Address Grand

Challenges in Plant Pathology

K.A. Garrett, R.I. Alcalá-Briseño, K.F. Andersen, C.E. Buddenhagen, R.A. Choudhury, 7.C. Fulton, 7.F. Hernandez Nopsa, R. Poudel, and $Y$. Xing

RNA Interference Mechanisms and Applications in Plant Pathology

Cristina Rosa, Yen-Wen Kuo, Hada Wuriyanghan, and Bryce W. Falk

Multiple-Disease System in Coffee: From Crop Loss Assessment to

Sustainable Management

Facques Avelino, Clémentine Allinne, Rolando Cerda, Laetitia Willocquet, and Serge Savary....

World Management of Geminiviruses

Maria R. Rojas, Monica A. Macedo, Minor R. Maliano, Maria Soto-Aguilar, Fuliana O. Souza, Rob W. Briddon, Lawrence Kenyon, Rafael F. Rivera Bustamante, F. Murilo Zerbini, Scott Adkins, James P. Legg, Anders Kvarnheden, William M. Wintermantel, Mysore R. Sudarshana, Michel Peterschmitt, Moshe Lapidot, Darren P. Martin, Enrique Moriones, Alice K. Inoue-Nagata, and Robert L. Gilbertson

\section{Errata}

An online log of corrections to Annual Review of Phytopathology articles may be found at http://www.annualreviews.org/errata/phyto 